\title{
High-Efficiency Solar Electricity of Umbrella by TRIZ Analysis
}

\author{
Jung-Hui Chao', Cheng-Yu Peng² \\ ${ }^{1}$ General Education Center, De Lin Institute of Technology, Taiwan \\ ${ }^{2}$ Green Energy and Environment Research Laboratories, Industrial Technology Research Institute, Taiwan \\ Email: cjh@dlit.edu.tw
}

Received 13 January 2016; accepted 13 February 2016; published 16 February 2016

Copyright (C) 2016 by authors and Scientific Research Publishing Inc.

This work is licensed under the Creative Commons Attribution International License (CC BY).

http://creativecommons.org/licenses/by/4.0/

(c) ()

\begin{abstract}
This investigation presents the strategy of high-efficiency solar electricity of umbrella by TRIZ (Theory of Inventive Problem Solving) analysis. According to the combined statistics of classical and new contradiction matrix, the invention principles can be used for designing tracking irradiance of surface plane of umbrella orientations including tilted angle $(\theta)$ and azimuth angle $(\emptyset)$. Three geographical sites are discussed by regions of Berlin, Taipei and Wellington located in north, near and south of tropic of cancer, respectively. The optimal design of azimuth surfaces of umbrella can be obtained by electricity gain at a fixed tilted angle.
\end{abstract}

\section{Keywords}

TRIZ, Electricity, Solar, Orientation, Umbrella

\section{Introduction}

The solar powered umbrella is designed to power the outdoor use of direct current electronic devices for replacing electrical outlets based on the benefit of providing shade for the user [1]. The factors of electricity include tilt angle and orientations of angular losses in the field condition [2]-[4], seasonal variations [5] and environment [6]. This research is to develop a strategy that suits for tracking high-efficiency solar electricity of umbrella by TRIZ (Theory of Inventive Problem Solving) analysis. By means of a practical methodology, tool sets, a knowledge base and model-based technology, TRIZ analysis helps to generate innovative solutions for problem solving. TRIZ stands for teoriya resheniya izobretatelskikh zadach (Russian: теория решения изобретательских задач), which is developed by the soviet inventor-Genrich Altshuller (1926-1998) and his working team between 1946 and 1985. TRIZ in English is typically rendered as "the theory of inventive problem solving" and it sometime goes as English acronym TIPS (Theory of Inventive Problem Solving) [7] [8]. 
The research has proceeded in several stages during the last sixty years. The three primary findings of this research are as follows:

- Problems and solutions are repeated across industries and sciences. The classification of the contradictions in each problem predicts the creative solutions to that problem.

- Patterns of technical evolution are also repeated across industries and sciences.

- TRIZ is used as the method and innovation principle of developing advanced technology and creative thinking. These principles should be identified and codified, and TRIZ could be taught to make the process of creativity more predictable [9]-[11].

According to geographical sites (latitude, longitude, time zone), tracking irradiance of surface plane of umbrella orientation (azimuth angle) would be one problem for high-efficiency solar electricity of umbrella. Another problem is that the degree of open umbrella (tilted angle) is limited by sun shadow area. The technology developed by TRIZ analysis takes care of these two problems. This work makes use of the TRIZ inventive principle of "transitioning to another dimension: another dimension, spheroidality, asymmetry, local quality, parameter changes". Since number of surface plane is optimal by azimuth angle analysis, sunlight is instead directed to go large irradiance and generate electricity gain.

\section{The Model Processes for Problem Solving with TRIZ}

\subsection{Theory and Model Processes of Inventive Problem Solving, TRIZ}

TRIZ is a problem solving method, which is based on logic and data, not by intuition or psychological inertia. It can accelerate the developer, research, and the project's working team has the ability to solve problems creatively. TRIZ also provides repeatability, predictability, and reliability due to its structure and algorithmic approach. TRIZ is an international science of creativity that relies on the study of the patterns of problems and solutions, not on the spontaneous and intuitive creativity of individuals or groups. More than three million patents have been analyzed to discover the patterns that predict breakthrough solutions to problems.

Creativity is now finding that solution and adapting it to this particular problem. An important part of the theory has been devoted to revealing patterns of evolution. Through TRIZ method, the innovative elements could be applied to the new innovative system, or even redefine the system characteristics and mode.

Most TRIZ practices are conducted by the pattern of repeating problems. This pattern not only helps deriving solutions to the problem but also meet the demand by using specific factors corresponding to the existing pattern. Figure 1 describes this process graphically, the arrows represent transformation from one formulation of the problem or solution to another. The steps problem solving approach forces the user to overcome inherent psychological bias that is typically the foundation of psychological ideation techniques.

\subsection{Engineering Parameters of the Contradiction Matrix}

Based on TRIZ by Altshuller, the specific problem is to face at the concept of the high-efficiency solar electricity of umbrella. Then using the problem transformation method changes the project to standard problem into 39 features, such as the problems of Length/Angle of stationary object, power, and function efficiency. The engineering concept defines generalizable patterns in the nature of inventive solutions and distinguishes characteristics of the problems that have been overcome through the spirit of hundreds of thousands of inventions. To specify a solution for the problem can get the invention principals from the contradiction matrix to solve the problem and enhance the value of this research.

The solar powered umbrella is designed to power the outdoor use of direct current electronic devices for replacing electrical outlets based on the benefit of providing shade for the user. As shown in Figure 2, the solar umbrella has several advantages as the base for the solar panels. The solar umbrella provides surface areas for mounting the solar panels allowed for easy exposure to sunlight. Therefore, solar collection capacity would be improved as the umbrella settling and solar panel design for integration. The graphs of sun path (height/azimuth diagram) reveal the characteristics and distribution of the meteorological diagram for any time period. In Figure 3, the geographical sites (latitude, longitude, time zone) are defined by regions of Berlin of Germany $(52.3,13.2,1)$ located in north of tropic of cancer, Taipei of Taiwan Region $(24.5,121.4,8)$ located near tropic of cancer and Wellington of New Zealand $(-41.19,174.46,12)$ located in south of tropic of cancer. The graphs of sun path perform transpositions from the yearly meteor information base on the database of PVSYST software. According to Sun 

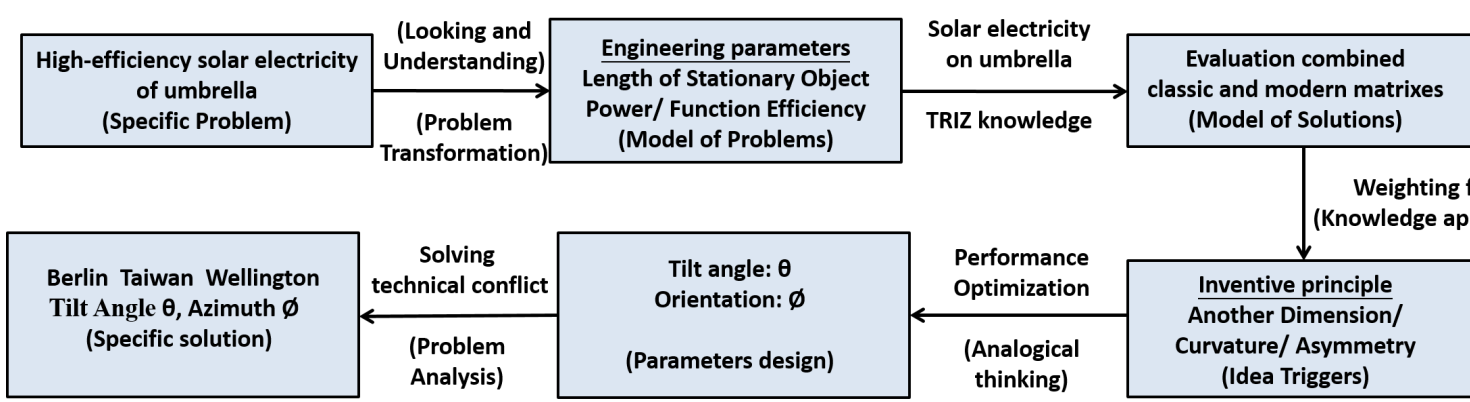

$\underset{\begin{array}{c}\text { Performance } \\ \text { Optimization } \\ \text { (Analogical } \\ \text { thinking) }\end{array}}{\leftarrow \text {. }}$

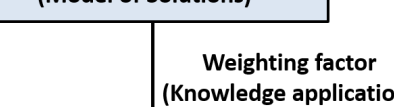

Figure 1. The model processes for problem solving with TRIZ.
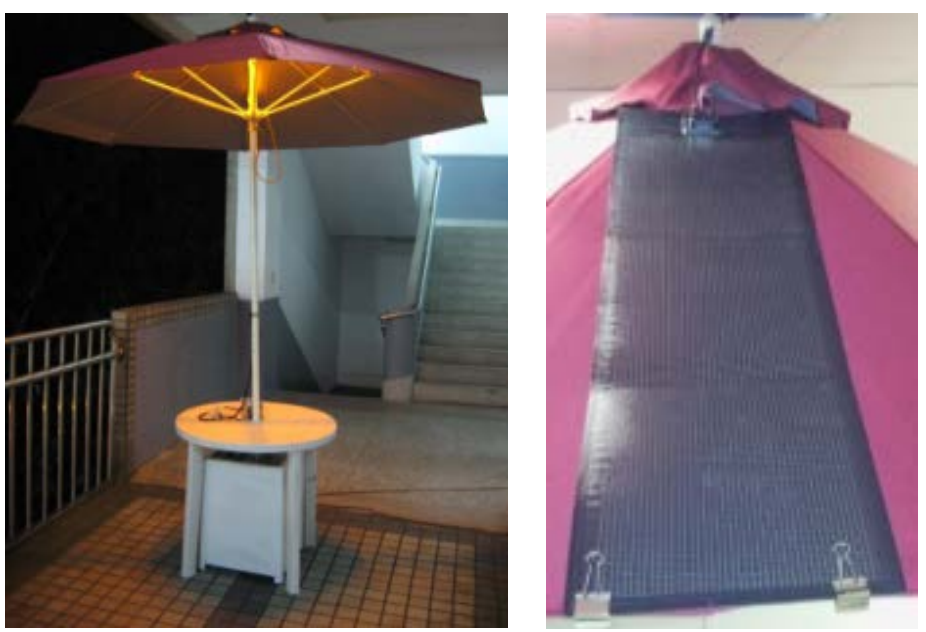

Figure 2. The solar umbrella and individual solar panel.

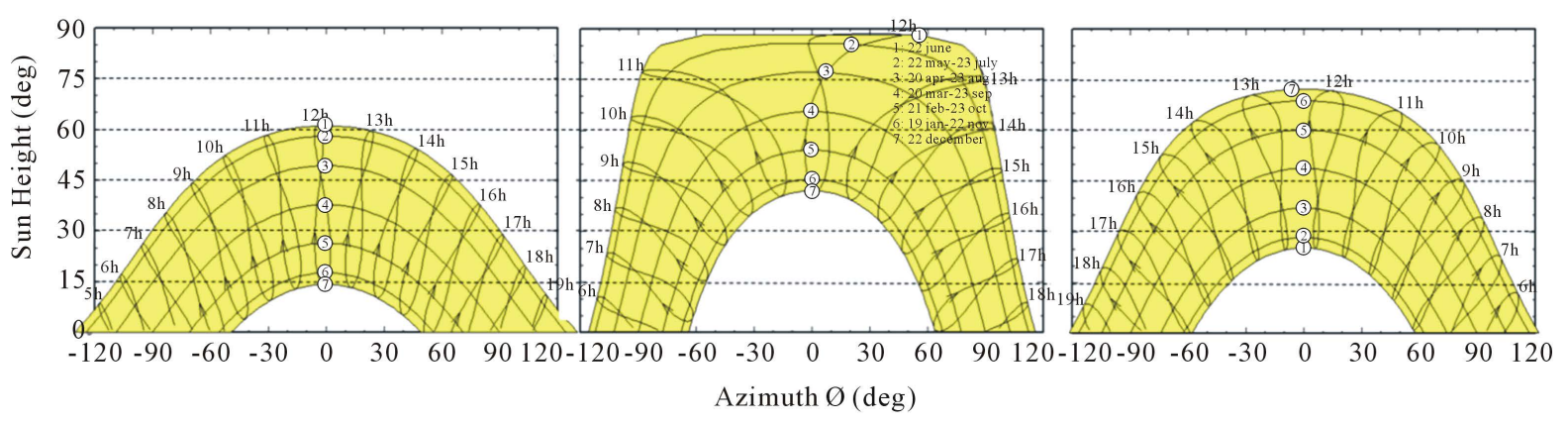

Figure 3. The geographical sites defined by regions of Berlin of Germany, Taipei of Taiwan Region and Wellington of New Zealand (from left to right).

path variations, TRIZ is applied to design parameters of umbrella founded by the classical and new contradiction matrix, and determined by settling orientation of solar panel for high-efficiency solar electricity of umbrella.

\section{The Combined Statistics of Classical and New Contradiction Matrix}

\subsection{TRIZ Analysis of Contradiction Matrix}

This paper applies a statistics with combined 39 engineering parameters and the 40 TRIZ principles to make a strategy suited for tracking high-efficiency solar electricity of umbrella. In Appendix 1, these are called the 39 Engineering Parameters. According to Altshuller extracted from over 1,500,000 world-wide patents, these 39 standard technical characteristics cause conflict. In Appendix 2, the 40 Principles are solution triggers, very general ideas of how to solve a contradiction. They are the easiest TRIZ tool to use, and the one most likely to 
give us good solutions fairly, easily and quickly. One of the tools which evolved as an extension of the 40 principles, and a contradiction matrix in the contradictory elements of a problem were categorized. According to a list of 9 engineering parameters (48 engineering parameters for the new version) it could impact on each other.

In Table 1 classic contradiction matrix is used to determine principles to the highest probability of solving a particular problem by finding the engineering parameters. Finding the contradictions to probable principles of TRIZ helps the analysis of a particular innovative problem to get the solution type of contradiction (39 engineering parameters/40 invention principles) directly. As high-efficiency solar electricity of umbrella for the class contradiction matrix, the 39 engineering parameters could be presented to solve the following:

4. Length/angle of stationary object.

6. Area of stationary object.

12. Shape.

21. Power.

In Table 2 new contradiction matrix (Darrell Mann Matrix) is used to determine principles to the highest probability of solving a particular problem by finding the engineering parameters. The new Matrix contains several parameters without the feature of classical Matrix. The inventive principle suggestions obtained from the original matrix for problems related to the new parameters (noise, emissions, safety, security, etc.) and from the nearest match of parameters in the original list of 39. Where there is no direct match between the conflict challenged by an inventor and the original matrix, the inventive principle suggestions are shown in parentheses (48 features/40 invention principles). For the New contradiction, the features are:
4. Length/angle of stationary object.
6. Area of stationary object.
9. Shape.
17. Energy used by stationary object.
18. Power.
24. Function efficiency.

Table 1. Classic contradiction matrix (39 engineering parameters/40 invention principles).

\begin{tabular}{lcccc}
\hline $\begin{array}{c}\text { Classic contradiction matrix } \\
\text { (39 engineering parameters/ } \\
40 \text { invention principles) }\end{array}$ & $\begin{array}{c}\text { 4. Length/angle of } \\
\text { stationary object }\end{array}$ & $\begin{array}{c}\text { 6. Area of stationary } \\
\text { object }\end{array}$ & 12. Shape & 21. Power \\
\hline $\begin{array}{l}\text { 4. Length/angle of stationary object } \\
\text { 6. Area of stationary object }\end{array}$ & - & $17,7,10,40$ & $13,14,15,7$ & 12,8 \\
12. Shape & $26,7,9,39$ & - & - & - \\
21. Power & 13,14 & - & 29,14 & 4,6 \\
\hline
\end{tabular}

Note: The sign “-” means no recommendations.

Table 2. New contradiction matrix (48 features/40 invention principles).

\begin{tabular}{lcrrrrr}
\hline $\begin{array}{l}\text { New contradiction matrix } \\
\text { (48 features/40 invention principles) }\end{array}$ & $\begin{array}{c}\text { 4. Length/angle } \\
\text { of stationary } \\
\text { object }\end{array}$ & $\begin{array}{c}\text { 6. Area of } \\
\text { stationary } \\
\text { object }\end{array}$ & 9. Shape & $\begin{array}{c}\text { 17. Energy used } \\
\text { by stationary } \\
\text { object }\end{array}$ & $\begin{array}{c}\text { 18. Power } \\
\text { 24. Function } \\
\text { efficiency }\end{array}$ \\
$\begin{array}{l}\text { 4. Length/angle of stationary object } \\
\text { 6. Area of stationary object }\end{array}$ & $17,14,3,4,7$ & 17,40 & $13,14,15,7$ & $35,3,30,31$ & 17,19 & $3,35,28$ \\
9. Shape & $17,14,4,13,5$, & $17,14,5$ & $17,5,4$ & $35,40,17$ & 35,7 & 28,3 \\
17. Energy used by stationary object & $4,7,9,19$ & $4,17,3,14,16$ & $7,35,24$ & 35,14 & $4,6,2,30,1$ & $2,29,28$ \\
18. Power & $17,14,1$ & $17,19,38$ & $29,14,15$ & 19,15 & $2,5,9,13$ & 2,19 \\
24. Function efficiency & $17,4,13,14$ & $14,17,4$ & $4,14,3,30$ & $3,35,19$ & $35,3,15,19$ & $2,28,14$
\end{tabular}




\subsection{Data Results of Contradiction Matrix by Combined Classic Contradiction Matrix and New Contradiction Matrix (Darrell Mann Matrix)}

The amount of the 40 principles is calculated by separated the classical and new contradiction matrix, which means to sum up the times of the invention principles is recommend by the matrixs. This paper applies statistics with combined the classical and new contradiction matrix to create new possibility as shown in Figure 4 . Comparing the classical and new contradiction matrix provides quantified data on how well the two matrices predict the inventive principles being used by recent inventors [12]. According to statistics, it describes that several invention principles could be used for the high-efficiency solar electricity of umbrella. The top 5 principles are the strategy ways of principle 17, 14, 3, 4, 35 as shown in Table 3.

\section{High-Efficiency Solar Electricity of Umbrella Designed by TRIZ}

\subsection{The Available Irradiation Analysis on Orientation Planes Founded by TRIZ}

The surface orientation of umbrella includes titled angle $(\theta)$ and azimuth angle $(\varnothing)$. And the tracking strategy of its surface orientation is determined by the results of the classical and new contradiction matrix to help optimizing the electrical yield. For Figure 5, the tilt angle of plane is defined as the angle between the plane and horizontal. The definition of the azimuth angles of plane is taken as negative toward east between south and irradiance collector plane (to go in the anti-trigonometric direction for northern hemisphere), and between north and

Table 3. Invention principles founded by the classical and new contradiction matrix.

\begin{tabular}{|c|c|c|}
\hline \multirow{2}{*}{$\begin{array}{c}\text { Principle No. } \\
\text { invention principle }\end{array}$} & \multicolumn{2}{|c|}{ Found by the classical and new contradiction matrix } \\
\hline & Principle description & Project application \\
\hline $\begin{array}{c}\text { Principle } 17 \\
\text { Another dimension }\end{array}$ & $\begin{array}{l}\text { - Transition one-dimensional movement, or } \\
\text { placement, of objects into two-dimensional; } \\
\text { two-dimensional to three-dimensional, etc. } \\
\text { - Incline an object, or place it on its side. } \\
\text { - Utilize the opposite side of a given surface. } \\
\text { - Project optical lines onto neighboring areas, } \\
\text { or onto the reverse side, of an object. }\end{array}$ & $\begin{array}{l}\text { Nowadays, the solar panel is always used to put on the top } \\
\text { of the roof and to settle as one single dimension or fix } \\
\text { direction. We found out there are some disadvantages for } \\
\text { this usage since the sun is rolling and the umbrella can } \\
\text { be rotated easily. So, we decide to move the solar from } \\
\text { one dimension to three-dimensional space for increasing } \\
\text { the efficiency of umbrella. }\end{array}$ \\
\hline $\begin{array}{l}\text { Principle } 14 \\
\text { Spheroidality }\end{array}$ & $\begin{array}{l}\text { - Instead of using rectilinear parts, surfaces, forms } \\
\text { or use curvilinear ones; move from flat surfaces } \\
\text { to spherical ones; from parts shaped as a cube } \\
\text { (parallelepiped) to ball-shaped structures. } \\
\text { - Go from linear to rotary motion, and use } \\
\text { centrifugal pattern. }\end{array}$ & $\begin{array}{l}\text { There are varied shapes of the umbrella, and we want to } \\
\text { use the solar panel to create the energy with high } \\
\text { efficiency, which means the shape or the tilt angle or } \\
\text { the length of the umbrella to find the highest efficiency. }\end{array}$ \\
\hline $\begin{array}{l}\text { Principle } 4 \\
\text { Asymmetry }\end{array}$ & $\begin{array}{l}\text { - Change the shape of an object from symmetrical } \\
\text { to asymmetrical. } \\
\text { - If an object is asymmetrical, increase its degree } \\
\text { of asymmetry. }\end{array}$ & $\begin{array}{l}\text { Although, symmetrical is easy to produce and storage, } \\
\text { the main purpose we are looking for is to improve the } \\
\text { functions and the efficiency of the solar umbrella. We } \\
\text { may analyze what kind of the structure is the suitable one, } \\
\text { we can think about solar panel amount and the number, } \\
\text { length, the angle of umbrella fin. }\end{array}$ \\
\hline $\begin{array}{c}\text { Principle } 3 \\
\text { Local quality }\end{array}$ & $\begin{array}{l}\text { - Change an object's structure from uniform } \\
\text { to non-uniform, and change an external } \\
\text { environment (or external influence) from } \\
\text { uniform to non-uniform. }\end{array}$ & $\begin{array}{l}\text { In spite of sitting under the umbrella, most of time it still } \\
\text { too hot and too dark to sit outside due to lack of lights and } \\
\text { electricity in the evening. So this research will use the } \\
\text { advantages and useful quality of each function to improve } \\
\text { and enhance the practicability of the solar umbrella. }\end{array}$ \\
\hline $\begin{array}{c}\text { Principle } 35 \\
\text { Parameter changes }\end{array}$ & - Change the degree of flexibility. & $\begin{array}{l}\text { How to make the energy and functionality of a solar umbrella } \\
\text { more efficiency becomes an important factor and objective } \\
\text { for this research. Sun is absolutely necessary for solar } \\
\text { function. With the variation of sun from east to west for } \\
\text { time to time, it makes many parameters of this subject, such } \\
\text { as the length of the fin, the angle, the amount of the fin, } \\
\text { even the power of the solar panel. }\end{array}$ \\
\hline
\end{tabular}




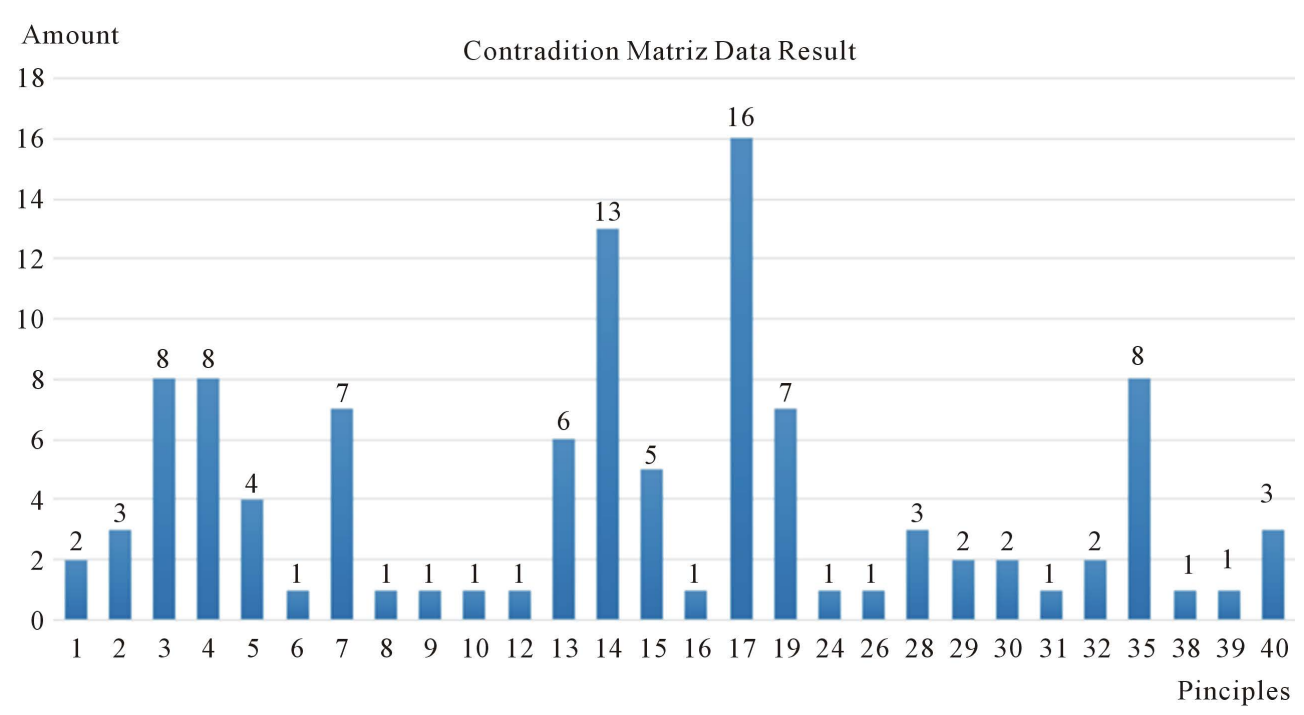

Figure 4. The statistics with combined the classical and new contradiction matrix.
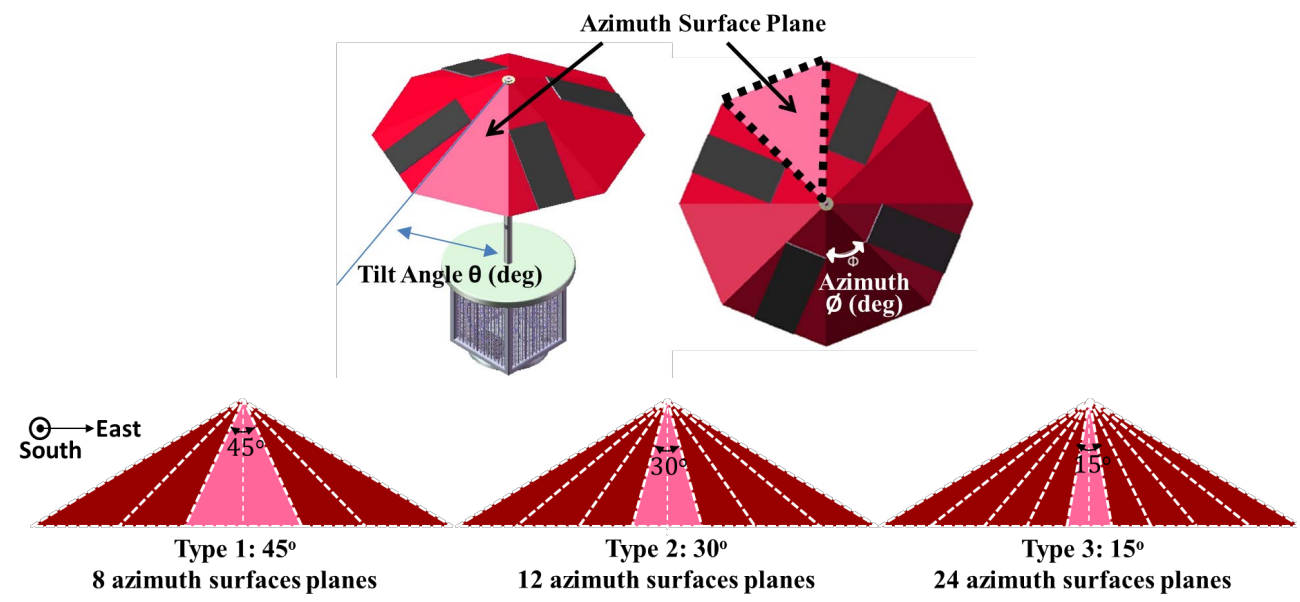

Figure 5. The tracking strategy with tilted angle $(\theta)$ and azimuth angle $(\varnothing)$ is determined by the result of the classical and new contradiction matrix.

irradiance collector plane (to go in the trigonometric direction for southern hemisphere). The tilted angle $(\theta)$ means the degree of open umbrella, and the azimuth angle $(\varnothing)$ shows how much umbrella surfaces could be mounted by solar panels. There are 3-type examples of umbrellas to discuss in this paper. Type 1: 8 umbrella azimuth surfaces planes represent 45 degree fan for individual solar panel and 8 total panels for 360 degree. Type 2: 12 umbrella azimuth surfaces planes represent 30 degree fan for individual solar panel and 12 total panels for 360 degree. Type 3: 24 umbrella azimuth surfaces planes represent 15 degree fan for individual solar panel and 24 total panels for 360 degree.

\subsection{Sky Radiance Model and Solar Yield}

The sky radiance model presents the incident solar radiation on an inclined surface [4] [13] [14]. The sum of direct-beam, sky-diffuse and ground reflection from the incident solar radiation transposes to an irradiance plane $\left(I_{g}\right)$ with an inclination angle

$$
\text { It can be given as } I_{g}=I_{b}+I_{d}+I_{r}
$$

where $I_{b}$ is direct-beam radiation on a plane $\left(\mathrm{Wh} / \mathrm{m}^{2}\right) ; I_{d}$ is sky-diffuse radiation on a plane $\left(\mathrm{Wh} / \mathrm{m}^{2}\right) ; I_{r}$ is ground reflection radiation on a plane $\left(\mathrm{Wh} / \mathrm{m}^{2}\right)$. 


$$
\begin{gathered}
\text { The direct-beam radiation: } I_{b}=\left(\frac{I_{h b}}{\sin \alpha}\right)\left(\sin \alpha \cos \theta+\cos \alpha \sin \theta \cos \left|\gamma-\gamma_{n}\right|\right) \\
\text { The ground reflection radiation: } I_{r}=\frac{\rho I_{h g}(1-\cos \theta)}{2}
\end{gathered}
$$

where $I_{h b}$ and $I_{h g}$ are horizontal direct beam radiation $\left(\mathrm{Wh} / \mathrm{m}^{2}\right)$ and horizontal global radiation $\left(\mathrm{Wh} / \mathrm{m}^{2}\right) . \alpha, \gamma$ and $\gamma_{n}$ are solar altitude (rad), solar azimuth (rad) and azimuth angle of the normal of the surface (rad), respectively.

$$
\text { The sky-diffuse radiation: } I_{d}=\sum_{i=1}^{n} R_{i} \omega_{i} \cos \sigma_{i}
$$

The sky-diffuse radiation can be calculated by the sum of $n$ products of $R_{i}, \omega_{i}$, and $\cos \sigma_{i}$, for each sky patch $i$. Solar radiation and sky radiance data have recorded during the 12-month period from January to December of PVGIS (Photovoltaic Geographical Information System) [15] and database were gathered for geographical assessment of the solar energy resource in the study.

The graph of transposition factor as a function of the plane tile and azimuth, and the optimization of the orientation depend on the planned use for the PV energy. When choosing the plane orientation, a plane indicated the corresponding transposition factor due to irradiance level. As shown in Figure 6, the geographical sites are discussed by regions of Berlin of Germany, Taipei of Taiwan Region and Wellington of New Zealand from left to right. The horizontal global irradiances of Berlin/Taipei/Wellington represent 1004/1529/1475 kWh/m² for whole year, 794/970/1054 kWh/m² for summer (October to March) and 210/558/421 kWh/m² for winter (April to September). By considering available irradiation on this orientation plane, the transposition factor (FT) shows the tilted/horizontal irradiation ratio for every plane related to the difference (loss) by the respect of the optimum orientation. The diffuse factor 1.0 is the attenuation of the diffuse irradiation part due to horizon shading. For north, near and south of tropic of cancer, the optimal point of irradiance plane revels large azimuth shift in winter.

\subsection{Solar Electricity Gain Designed by Surface Plane Types of Umbrella}

The umbrella has diameter of 2.7 meter and surface plane equal to area of $5.726 \mathrm{~m}^{2}$. The solar panel has maximum power point of $147 \mathrm{Wp} / \mathrm{m}^{2}$ by multi-crystalline silicon solar cell. The individual solar panels mounting on surface of umbrella operate in parallel connection. In Figure 7 the electricity of normalized system production is resulted by the three type designs (type 1 with 8 umbrella surfaces, type 2 with 12 umbrella surfaces and type 3 with 24 umbrella surfaces). The different types reveal electricity performances that depended on the degree of open umbrella (tilt angle $\theta$ ), especially for the regions of north (Berlin) and south (Wellington) of tropic of cancer. In general, the optimal tilt angles $\theta$ with fixed azimuth angle of south in winter are 59 in Berlin, 38 in Taipei and 60 in Wellington, respectively. If the different typesof aziumth of umbrella are applied, the shifted optimal tilt angles were founded by 50 in Berlin, 30 in Taipei and 45 in Wellington. The results is simular as properties on orientation and inclination angle of the roof in Germany [16], when tilt angle decresced with orentation increasing.
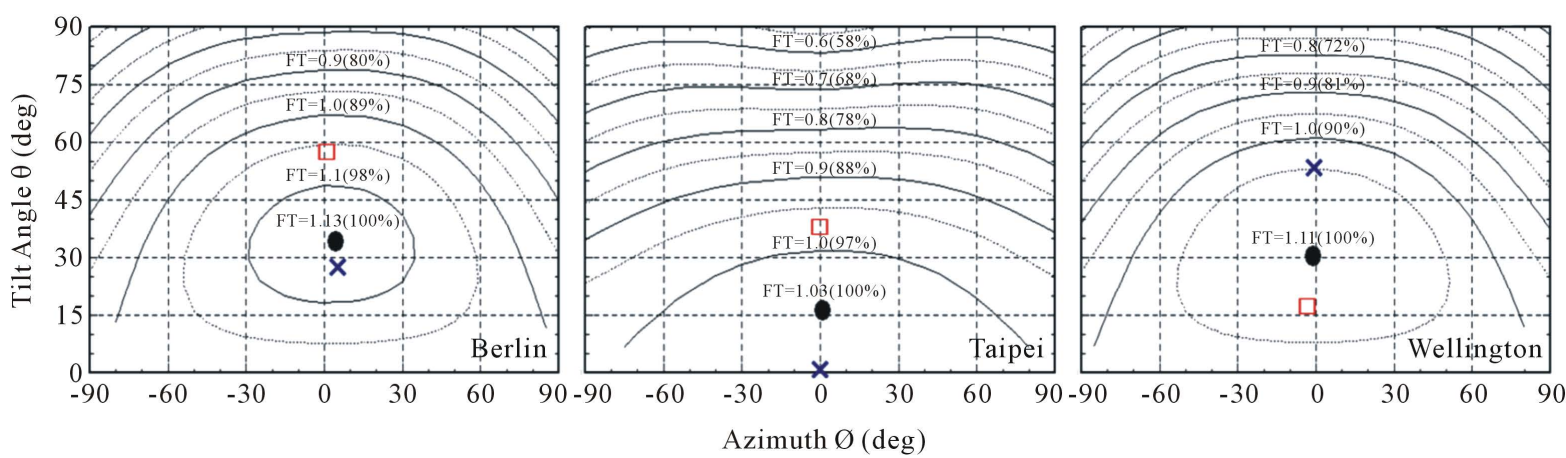

Figure 6. The available irradiation on orientation plane (tilt $\theta$ and azimuth) by the tilted/horizontal irradiation ratio (red square: winter, blue cross: summer, black dot: whole year). 
In order to obtain the electricity gain compared with reference of type 1, the different types of azimuth of umbrella are calculated by electricity of normalized system production in Figure 8. The gain of type 3/type 2 at fixed tilted angle $(\theta)$ of $50^{\circ}$ are $1.366 \% / 0.819 \%$ in Wellington, $1.070 \% / 0.669 \%$ in Berlin, $0.658 \% / 0.411 \%$ in Taipei, respectively. The electricity performance can be improved by the designs of type 3 with 24 umbrella surfaces represent 15 degree fan for individual solar panel and 24 total panels in parallel connection for 360 degree.

\section{Conclusion}

In this study, the strategy of high efficiency solar electricity of umbrella can be founded by combining the classical and new contradiction matrix of TRIZ base on the statistics and designed as different types of azimuth surface planes. The electricity gain of $1.366 \%$ at fixed tilted angle $(\theta)$ of $50^{\circ}$ can be resulted by the designs of type 3 with 24 umbrella surfaces compared with type 1 . The design of type 3 shows 15 degree fan for individual solar panel, and 24 fans in parallel connection for 360 degree of umbrella. By analyzing the graph of transposition factor as a function of the plane tile and azimuth, the optimization of the orientation can be obtained to the planned use for the PV energy. The optimal point of irradiance plane reveals large azimuth shift in winter. The different types show electricity performances depended on the degree of open umbrella (tilt angle $\theta$ ), especially for the regions of north (Berlin) and south (Wellington) of tropic of cancer. This study presents the different types of aziumth of umbrella with shifted optimal tilt angles founded by 50 in Berlin, 30 in Taipei and 45 in Wellington.

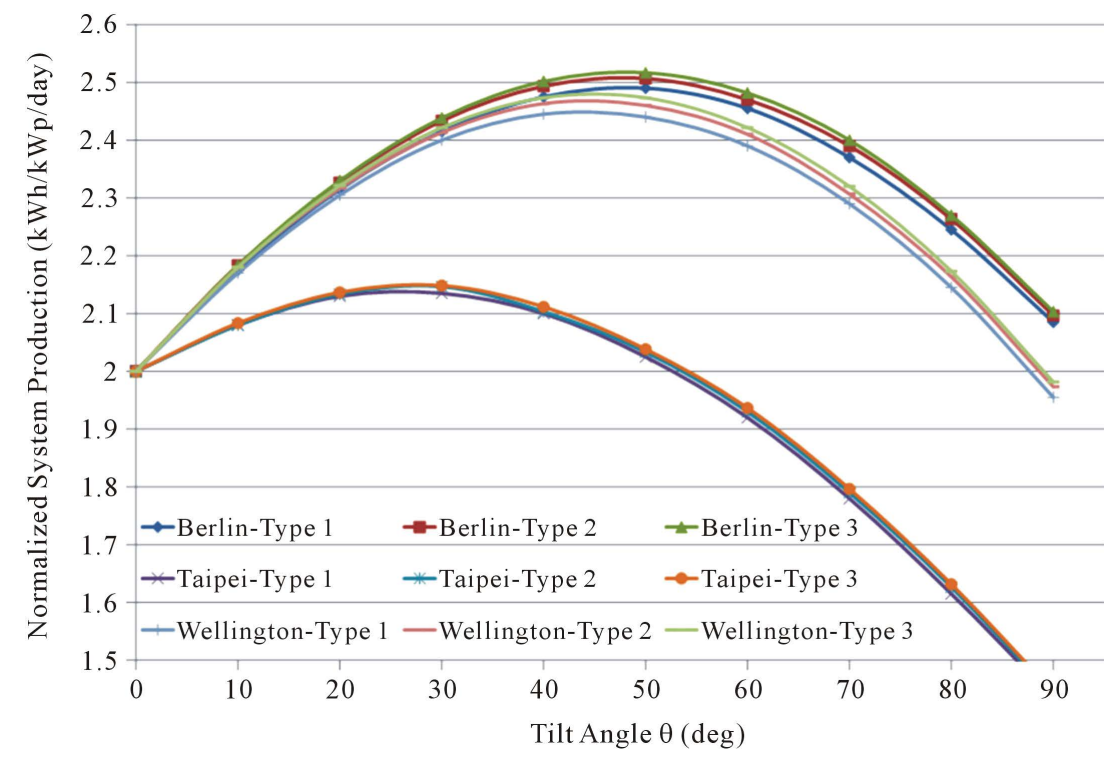

Figure 7. The electricity of normalized system production is resulted by the three type designs for shifted optimal tilt angles.

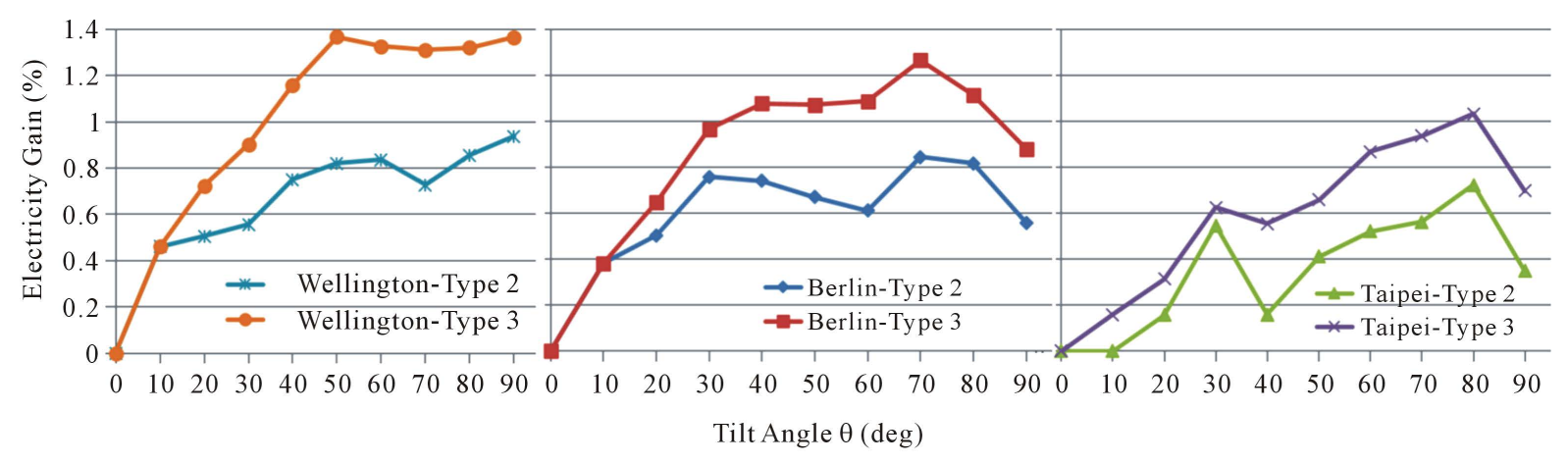

Figure 8 . The electricity gain to type 3/type 2 compared with reference of type 1 in Wellington, Berlin and Taipei. 


\section{Acknowledgements}

The authors would like to thank the Taiwan Bureau of Energy for the financial support, related research plan and resource by Industrial Technology Research Institute.

\section{References}

[1] DeVoss, M. (2011) 60 Watt Embedded Solar Cell Umbrella. Senior Project, California Polytechnic State University, San Luis Obispo.

[2] Martin, N. and Ruiz, J.M. (2001) Calculation of the PV Modules Angular Losses under Field Conditions by Means of an Analytical Model. Solar Energy Materials \& Solar Cells, 70, 25-38. http://www.sciencedirect.com/science/article/pii/S0927024800004086 http://dx.doi.org/10.1016/S0927-0248(00)00408-6

[3] Kacira, M., Simsek, M., Babur, Y. and Demirkol, S. (2004) Determining Optimum Tilt Angles and Orientations of Photovoltaic Panels in Sanliurfa, Turkey. Renewable Energy, 29, 1265-1275.

http://www.sciencedirect.com/science/article/pii/S0960148104000060 http://dx.doi.org/10.1016/j.renene.2003.12.014

[4] Li, H.W. and Lam, N.T. (2007) Determining the Optimum Tilt Angle and Orientation for Solar Energy Collection Based on Measured Solar Radiance Data. International Journal of Photoenergy, 2007, Article ID: 85402. http://www.hindawi.com/journals/ijp/2007/085402/abs/ http://dx.doi.org/10.1155/2007/85402

[5] Riither, R. and Livingstone, J. (1994) Seasonal Variations in Amorphous Silicon Solar Module Outputs and Thin Film Characteristics. Solar Energy Materials \& Solar Cells, 36, 29-43. http://www.sciencedirect.com/science/article/pii/0927024894001650 http://dx.doi.org/10.1016/0927-0248(94)00165-O

[6] Asl-Soleimani, E., Farhangi, S. and Zabihi, M.S. (2001) The Effect of Tilt Angle, Air Pollution on Performance of Photovoltaic Systems in Tehran. Renewable Energy, 24, 459-468. http://www.sciencedirect.com/science/article/pii/S0960148101000295 http://dx.doi.org/10.1016/S0960-1481(01)00029-5

[7] Altshuller, G. (1988) Creativity as an Exact Science. Translated by Anthony Williams. Gordon \& Breach, NY.

[8] Domb, E. (1997) Contradictions. The TRIZ Journal. http://www.triz-journal.com

[9] Terninko, J., Zusman, A. and Zlotin, B. (1997) Step-by-Step TRIZ. Nottingham, NH.

[10] The Invention Machine Laboratory ${ }^{\mathrm{TM}}$ Version 1.4, Help Files. http://www.triz-journal.com/seventy-six-standard-solutions-relate-40-principles-inventive-problem-solving/

[11] Altov, H. (1995) (G. Altshuller Pseudonym) and Suddenly the Inventor Appeared. Translated by Lev Shulyak, Technical Innovation Center, Worcester.

https://www.google.com.tw/url?sa=t\&rct=j\&q=\&esrc=s\&source=web\&cd=1\&cad=rja\&uact=8\&ved=0ahUKEwjmrJC kl6XKAhXFHpQKHe0FACEQFggcMAA\&url=http\%3A\%2F\%2Fwww.evolocus.com\%2FTextbooks\%2FAltshuller2 004.pdf\&usg=AFQjCNGUWfhDmXGjVWvPNabC4tB7PicgWA\&sig2=unIpWT_oxEsz31fXjZo2VQ

[12] Mann, D. (2004) Comparing the Classical and New Contradiction Matrix. The TRIZ Journal. http://www.triz-journal.com/comparing-classical-new-contradiction-matrix-part-2-zooming/

[13] Li, D.H.W., Cheung, G.H.W. and Lam, J.C. (2005) Analysis of the Operational Performance and Efficiency Characteristic for Photovoltaic System in Hong Kong. Energy Conversion and Management, 46, 1107-1118. http://www.sciencedirect.com/science/article/pii/S0196890404001682 http://dx.doi.org/10.1016/j.enconman.2004.06.029

[14] Balouktsis, A., Karapantsios, T.D., Anastasiou, K., Paschaloudis, D., Bezergiannidou, A. and Bilalis, N. (2006) Sizing Stand-Alone Photovoltaic Systems. International Journal of Photoenergy, 2006, Article ID: 73650. http://www.hindawi.com/journals/ijp/2006/073650/abs/ http://dx.doi.org/10.1155/ijp/2006/73650

[15] PVGIS (Photovoltaic Geographical Information System) Is a Part of the SOLAREC Action at the JRC Renewable Energies Unit for Geographical Assessment of the Solar Energy Resource. http://re.jrc.ec.europa.eu/pvgis/info/faq.htm\#PVGIS http://iet.jrc.ec.europa.eu/renewable-energies

[16] Geißler, C. and Zentgraf, E. (2013) Not Only for Roofs Oriented South but Also for Roofs Oriented East and West-, TEC-Institute for Technical of Germany. http://www.tec-institut.com/solar-power-supply-up-to-75-grid-independent-in-the-center-of-germany-for-private-and-i ndustrial-consumers-via-storage-accumulators/ 
Appendix 1. List Table of 39 Engineering Parameters

\begin{tabular}{|c|c|}
\hline 1 & Weight of moving object \\
\hline 2 & Weight of stationary object \\
\hline 3 & Length of moving object \\
\hline 4 & Length of stationary object \\
\hline 5 & Area of moving object \\
\hline 6 & Area of stationary object \\
\hline 7 & Volume of moving object \\
\hline 8 & Volume of stationary object \\
\hline 9 & Speed \\
\hline 10 & Force \\
\hline 11 & Stress or pressure \\
\hline 12 & Shape \\
\hline 13 & Stability of the object's composition \\
\hline 14 & Strength \\
\hline 15 & Duration of action by a moving object \\
\hline 16 & Duration of action by a stationary object \\
\hline 17 & Temperature \\
\hline 18 & Illumination intensity \\
\hline 19 & Use of energy by moving object \\
\hline 20 & Use of energy by stationary object \\
\hline 21 & Power \\
\hline 22 & Loss of energy \\
\hline 23 & Loss of substance \\
\hline 24 & Loss of information \\
\hline 25 & Loss of time \\
\hline 26 & Quantity of substance/the matter \\
\hline 27 & Reliability \\
\hline 28 & Measurement accuracy \\
\hline 29 & Manufacturing precision \\
\hline 30 & External harm affects the object \\
\hline 31 & Object-generated harmful factors \\
\hline 32 & Ease of manufacture \\
\hline 33 & Ease of operation \\
\hline 34 & Ease of repair \\
\hline 35 & Adaptability or versatility \\
\hline 36 & Device complexity \\
\hline 37 & Difficulty of detecting and measuring \\
\hline 38 & Extent of automation \\
\hline 39 & Productivity \\
\hline
\end{tabular}




\section{Appendix 2. List Table of 40 Principles}

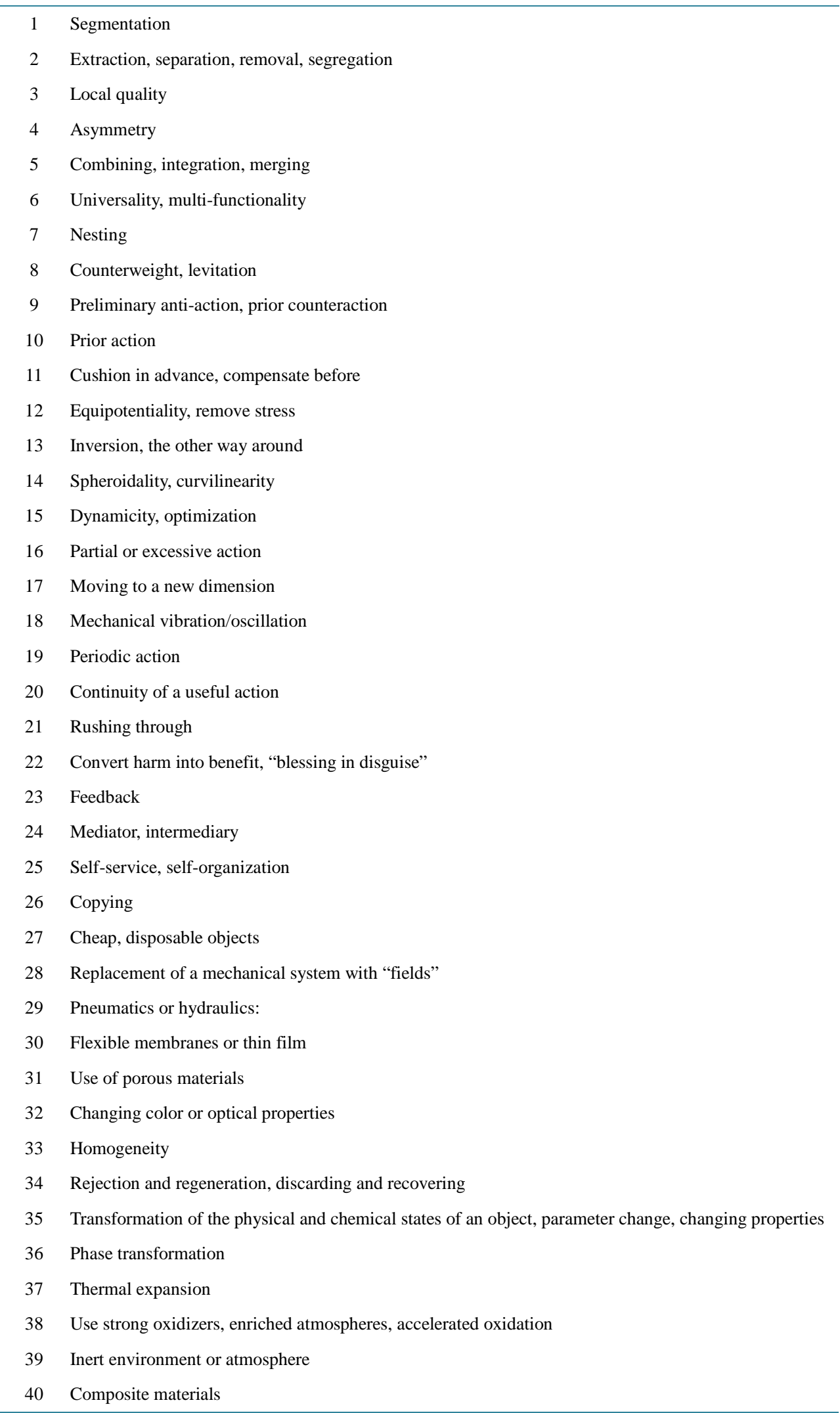

